\title{
FUNCTIONAL AND RADIOGRAPHIC EVALUATION OF 214 AGGRESSIVE BENIGN BONE LESIONS TREATED WITH CURETTAGE, CAUTERIZATION, AND CEMENTATION: 24 YEARS OF FOLLOW-UP
}

Olavo Pires de Camargo, Alberto Tesconi Croci, Cláudia R.G.M.C. de Oliveira, André Mathias Baptista, and Marcelo Tadeu Caiero

$\overline{\text { Camargo OP de, Croci AT, Oliveira CRGMC de, Baptista AM, Caiero MT. Functional and radiographic evaluation of } 214}$ aggressive benign bone lesions treated with curettage, cauterization, and cementation: 24 years of follow-up. Clinics. 2005; 60(6):439-44.

PURPOSE: Treatment with curettage, cauterization, and methylmethacrylate of aggressive benign bone lesions is a method now widely accepted in most orthopedic oncology centers. However, one of the controversies regarding this technique is the possible complications that may arise from the use of methylmethacrylate, which has caused some authors to remove it 2 years after the surgery and replace it with bone graft. The objective of this paper is to present a functional and radiographic evaluation of 214 patients presenting with aggressive benign bone lesions treated with curettage, cauterization, and methylmethacrylate from 1974 to 1998 , with some of them having 24 years of follow-up. These patients were clinically and radiographically evaluated for the incidence of late osteoarthrosis, range of motion, and pain in the involved joint.

METHOD: This study comprised 214 patients, with an average follow-up duration of 10.6 years (range : 2 to 24 years. All cases involved aggressive benign lesions. The patients were evaluated according to the Musculoskeletal Tumor Society Score (MSTS) functional evaluation system, and the complications are described.

RESULTS: The MSTS functional evaluation was excellent in 166 cases (78\%), good in 26 (12\%), fair in 11 (5\%), and poor in 11 $(5 \%)$. The following complications were observed: late osteoarthrosis, 25 cases (12\%); infection, 12 (6\%); pathologic fracture, 11 (5\%); and local recurrence, $19(9 \%)$.

CONCLUSION: Based on clinical assessment, no significant deleterious effects directly related to the use of methylmethacrylate were observed. The functional evaluation performed in 1998 (up to 24 years of follow-up) did not show significant change when compared to the evaluation performed in 1985 .

\section{KEYWORDS: Giant cell tumors. Curettage. Cementation.}

Although many authors ${ }^{1-10}$ have already demonstrated the good results of curettage and methylmethacrylate in the treatment of giant cell tumors and other aggressive benign bone lesions, we are not aware of any report on large series of cases with long-term evaluation discussing possible deleterious effects of the cement, as most of these le-

Orthopedic Oncology Group, Department of Orthopedics, Hospital das Clinicas, São Paulo University Medical School - São Paulo/SP - Brazil. Email: olapcama@uol.com.br

Received for publication on May 31, 2005.

Accepted for publication on August 24, 2005. sions occur close to weight-bearing joints. Many factors have contributed to the increased use of bone cement as an adjuvant in the treatment of these lesions, such as less surgical morbidity, early recurrence detection, minimal functional deficit, and a lower recurrence rate.

Although there is some concern that the heat generated by the methylmethacrylate may lead to tumor necrosis, ${ }^{11-}$ ${ }^{12}$ the recurrence rate observed in most oncology orthopedics services is around $9 \% .^{3}$ Other types of local adjuvants have been employed separately or in association with the cement, such as liquid nitrogen ${ }^{12,13}$ and phenol, ${ }^{8}$ which is 
also associated with a low rate of recurrence but with a higher morbidity. We have routinely used meticulous cauterization of the cavity along with cement to enhance the destruction of the tumor cells.

The objective of this work is to present the functional results during long-term follow-up of up to 24 years for 214 patients presenting with aggressive benign bone lesions treated by the same team of surgeons using the same method. These patients were clinically and radiographically re-evaluated for the occurrence of late degenerative changes, progressive loss of range of motion, and pain in the affected joint.

\section{MATERIALS AND METHODS}

This study comprises 214 patients treated at the Department of Orthopedics of Hospital das Clinicas, Faculty of Medicine, University of São Paulo, between 1974 and 1998, with confirmed histological diagnosis of benign aggressive bone tumors of the following types: 135 giant cell tumors, 38 aneurysmal bone cyst, 22 chondroblastomas, 10 chondromyxoid fibromas, and 9 osteoblastomas. Patient ages ranged from 2 to 63 years with an average of 30.6 years.

Of the 214 patients, 115 were male and 99 female (Figure 1). The average follow-up time was 10.6 years, ranging from 2 to 24 years. The anatomical sites involved were as follows: distal femur (99 cases), proximal tibia (50), distal radius (24), proximal femur (15), distal tibia (8), proximal humerus (6), distal humerus (4), sacrum (4), and phalanges (4) (Figure 2).

All lesions were classified according to the system of Campanacci et al. ${ }^{14}$ for giant cell tumors as follows: 86 grade I (intraosseous), 103 grade II (cortical thinning); and 25 grade III (cortical rupture) (Figure 3). The criterion for employing this treatment method, including grade III lesions, was the presence of at least 2 walls of the cavity still intact.

\section{Operative Technique}

The surgical procedure did not change from our previous publications with the following exception: since 1986, we have not been using a polyethylene piece fitted according to the size of the lesion to fill the cavity, as can be noted for cases with longer follow-up (Figure 4). It is important to emphasize that we also performed the cauterization of the whole surface after meticulous curettage and then used a high-speed burr as a second local adjuvant. After this procedure, the cavity was rinsed again, and the methylmethacrylate bone cement was packed under pressure into the cavity, making certain that no empty space was left. We did not protect the articular cartilage. To decrease the risk of pathologic fracture in larger defects with cortical destruction, we inserted intramedullary Ender nails before applying the cement.

After the fifth year of surgery, all patients were followed postoperatively on an annual basis with clinical exams and plain X-rays to determine whether the Musculoskeletal Tumor Society Score (MSTS) functional evaluation system revealed any significant change in terms of pain, loss of joint mobility, or degenerative changes visible in plain radiographs, when compared to the functional evaluation of 1985 .
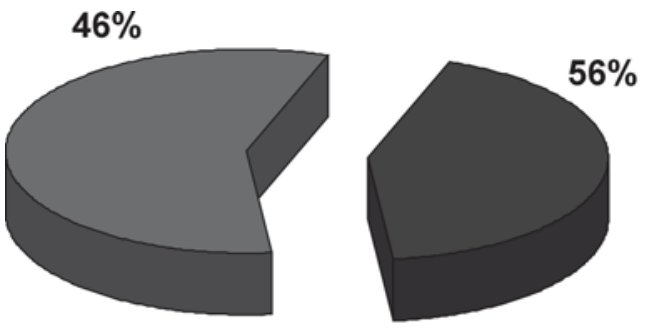

Figure 1 - Gender

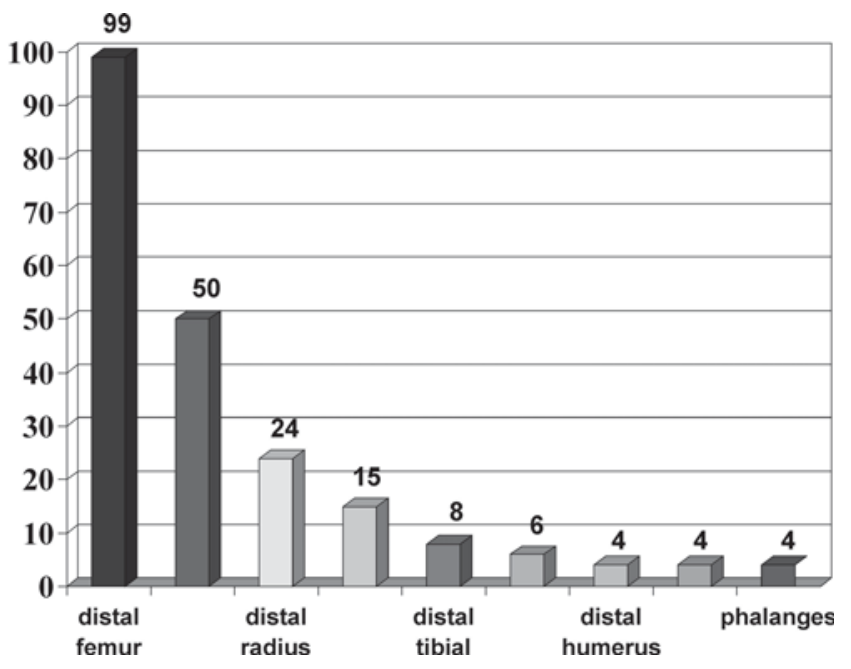

Figure 2 - Localization

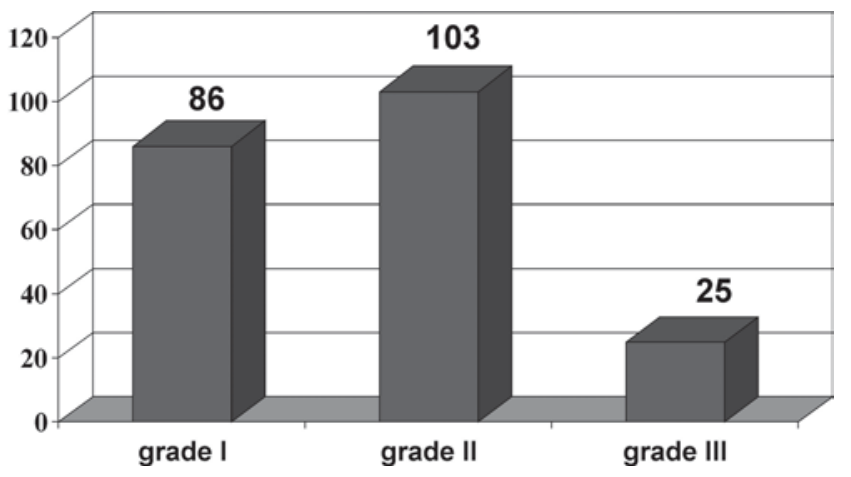

Figure 3 - Campanacci Grade 

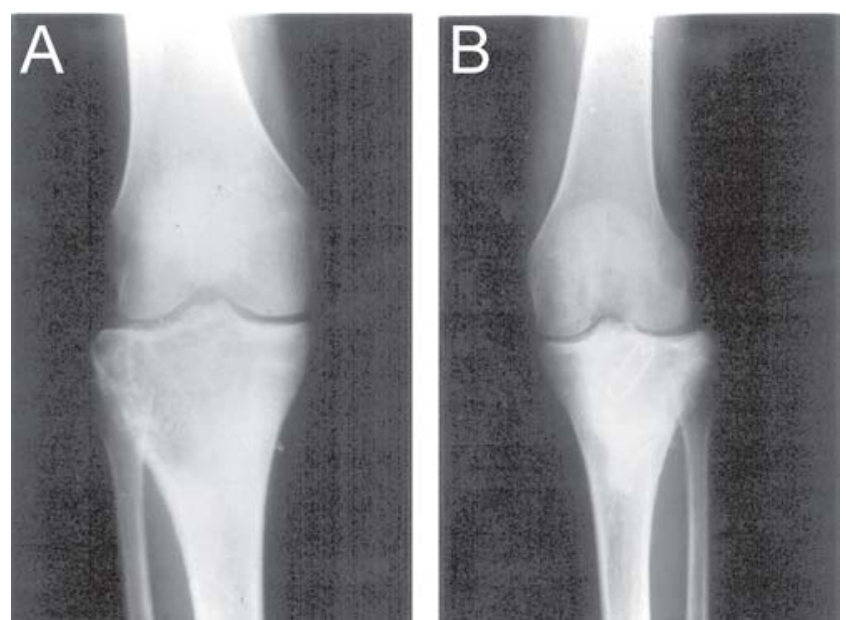

Figure 4 - A) Giant cell tumor of proximal tibia. B) Pos-operative radiography

\section{Inclusion Criteria}

1. Patients with B3 aggressive benign bone tumor proven by radiographic and histologic evaluation and by rapid growth within weeks.

2. No involvement, as yet, of the joint adjacent to the tumor, thus allowing the use of a marginal resection technique rather than ample resection and placement of an endoprosthesis.

3. Absence of any histologic evidence of a malignant neoplasm.

\section{Exclusion Criteria}

1. Patients with $\mathrm{B} 1$ or $\mathrm{B} 2$ nonaggressive benign tumors that did not justify the use of a local adjuvant—ie, a case for which a bone graft could be used with no risk of local recurrence.

2. Significant destruction of the adjoining joint, with injury to the joint cartilage, thus making it impossible to perform a marginal resection surgery-ie, a case for which an ample resection with the placement of an endoprosthesis was advisable.

\section{RESULTS}

All 214 patients were followed from 2 to 24 years (an average of 10.6 years). The complications were: local recurrence (19 cases, 9\%), which were reoperated on with cementation); infection (12 cases, 6\%), which were revised and rated good ( 8 cases) and poor ( 4 cases); pathologic fracture (11 cases, $5 \%$ ), which were rated fair in the functional evaluation; and late osteoarthrosis (25 cases, 12\%), most of them corresponding to the cases classified as grade III according to Campanacci's system).
The results, according to the MSTS functional evaluation system, were as follows (Figure 5):

Excellent: $166(78 \%)$

Good: $26(12 \%)$

Fair: $11(5 \%)$

Poor: $11(5 \%)$

No deaths occurred during the evaluation period.

It was not possible to perform a complete follow-up of all patients, mainly on account of difficulties relating to the update of medical records of patients in out Institution..

\section{DISCUSSION}

The use of local adjuvants in the management of aggressive benign bone lesions is now well defined, particularly for giant cell tumors. Liquid nitrogen, phenol, and methylmethacrylate are the most commonly employed methods, decreasing the overall recurrence rate to $9 \%$.

Although there is some controversy as to whether the heat generated by the polymerization is enough to destroy tumor cells $s^{6,12,15-19}$ many authors have already demonstrated that the recurrence rate is similar to other local procedures. ${ }^{5}$ The advantages of using cement include less morbidity and postoperative complications, avoidance of unnecessary bone autograft, earlier detection of recurrence, and immediate recovery without functional deficit. Our department has used cauterization of the inner walls of the cavity along with cement since 1974, because we believe that it can increase the necrosis depth up to $2 \mathrm{~mm}$ (Figure 5). We believe that another important aspect to be considered for success in the use of cement is that it fills the cavity uniformly and completely, without any empty spaces, possibly contributing to the reduced incidence of recurrence; this does not happen when the cavity is filled with bone graft.

Regarding complications, we had a number of cases of pathologic fracture; most of them with large, grade III lesions with cortical rupture. They were reoperated on without the necessity of cement removal, and the functional end

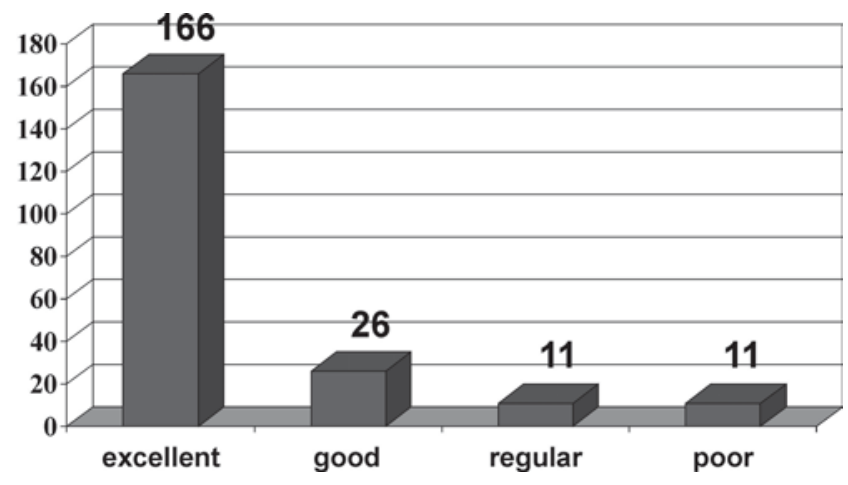

Figure 5 - Functional result 
result was fair., Infections were superficial, and in none of them was it necessary to perform a radical procedure, but rather only a surgical revision, with good outcome.

We elected this technique even in cases of large lesions, classified as grade III (25 patients), instead of performing major reconstructive surgery. In cases with knee involvement, we believe that if the pain and the limitation of range of motion increases after a long-term appraisal, it is always possible to perform a surgical revision to a total knee arthroplasty. So far, it has not been necessary to perform a surgical revision due to degenerative arthritis.

Notably, evidence of degenerative arthritis observed in cases with longer follow-up (more than 15 years) was more of a radiographic than of a clinicalnature, as patients pre- sented only mild pain and knee effusion with some degree of joint limitation; functional evaluation was returned. We cannot determine whether these cases of arthritis were due to the cement itself or to the subchondral location of the lesion. The 1998 MSTS functional evaluation showed no significant difference when compared to the 1985 clinical survey.

Although nothing was proved experimentally regarding whether the methylmethacrylate cement objectively contributed to the low rate of recurrence in this series, we feel confident that after 24 years of experience with 214 cases, this technique is a reliable, safe, and simple method of treatment, not only for giant cell tumors, but also for other aggressive benign lesions.

\section{RESUMO}

Camargo OP de, Croci AT, Oliveira CRGMC de, Baptista AM, Caiero MT. Avaliação radiográfica e funcional de 214 lesões ósseas benignas agressivas tratadas com curetagem, cauterização e cimentação: 24 anos de seguimento. Clinics. 2005; 60(6):439-44.

OBJETIVO: O tratamento com curetagem cauterização e metilmetacrilato de lesões ósseas benignas agressivas é o método agora amplamente aceito em quase todos os Centros Ortopédicos Oncológicos, entretanto uma das controvérsias com relação a esta técnica são as possíveis complicações que podem sugerir com o uso do metilmetacrilato fazendo com que alguns autores o removam dos anos depois da cirurgia e os substituam com o enxerto ósseo. O objetivo deste trabalho é apresentar a avaliação radiográfica e funcional de 214 pacientes apresentando lesões ósseas benignas agressivas tratadas com curetagem, cauterização e metilmetacrilato de 1974 a 1998, sendo que alguns deles tem 12 anos de seguimento. Esses pacientes foram avaliados clínica e radiograficamente para a ocorrência de osteoartrose tardia, amplitude de movimento e dor na articulação envolvida. 
MÉTODO: Este estudo é constituído de 214 pacientes, com seguimento médio de 10,6 anos (2 a 24 anos). Todos os casos correspondem as lesões benignas agressivas. Os pacientes foram avaliados de acordo com Muscolskeletal Tumor Society Score sendo descritas as complicações.

RESULTADOS: A avaliação funcional da (MSTS) foi excelente em 166 casos (78\%), bom em 26 (12\%), regular em $11(5 \%)$ e mal $11(5 \%)$. Foram observadas as seguintes complicações: osteoartrose tardia 25 casos (12\%), infecção $12(6 \%)$, fratura patológica $11(5 \%)$ e rescindiva local 19(9\%).
CONCLUSÃO: Baseado na abordagem clínica não foi observado efeitos deletérios diretamente relacionados ao uso do metilmetacrilato. A avaliação funcional realizada em 1998 (até 24 anos de seguimento) não apresentou alterações significantes quando comparadas a avaliação realizada em 1985.

PALAVRAS-CHAVE: Tumores de células gigantes. Curetagem. Cimentação.

\section{REFERENCES}

1. Camargo FP, Camargo OP. Surgical treatment of benign cavitary bone lesions using methylmethacrylate cement and polyethylene prosthesis: experience with 135 cases. In: Enneking WF, editor. Limb salvage in musculoskeletal oncology. New York: Churchill Livingstone; 1987. p. 527.

2. De Camargo OP. Curettage of giant cell tumor of bone. Complications. Chir Organi Mov. 1990;75(1 Suppl):209-11.

3. Capanna R, Fabri N, Bettelli G. Curettage of giant cell tumor of bone. The effect of surgical technique and adjuvants on local recurrence rate. Chir Organi Mov. 1990;75(1 Suppl): 206.

4. Conrad III EU, Enneking WF, Springfield DS. Giant-cell tumor treated with curettage and cementation. In: Enneking WF, editor. Limb salvage in musculoskeletal oncology. New York: Churchill Livingstone; 1987. p. $516-9$.

5. Johnston J. Treatment of giant-cell bone tumors by aggressive curettage and packing with bone cement. In: Enneking WF, editor. Limb salvage in musculoskeletal oncology. New York: Churchill Livingstone; 1987. p. 512-6.

6. Leeson MC, Lippit SB. Thermal aspects of the use of polymethylmethacrylate in large metaphyseal defects in bone. A clinical review and laboratory study. Clin Orthop. 1993;295:239-45.

7. Persson BM, Wouters HW. Curettage and acrylic cementation in surgery of giant cell tumors of bone. Clin Orthop. 1976;120:125-33.
8. Rock M. Adjuvant management of benign tumors; basic concepts of phenol and cement use. EMSOS-MSTS Joint study of giant cell tumor of bone. Chir Organi Mov. 1990;75(1Suppl):195-7.

9. Taminiau AHM, Wouters HW. Treatment of giant cell tumors by curettage and acrylic cementation. In: Enneking WF, editor. Limb salvage in musculoskeletal oncology. New York: Churchill Livingstone; 1987. p. 477.

10. Etchebehere M, Camargo OP, Croci AT Oliveira CRCM, Batista AM. Relationship between surgical procedure and outcome for patients with grade I chondrosarcomas. Clinics. 2005;60:121-126.

11. Willert HG. Clinical results of the temporary acrylic bone cement plug in the treatment of bone tumors: a multicentric study. In: Enneking WF, editor. Limb salvage in musculoskeletal oncology. New York: Churchill Livingstone; 1987. p. 445-58.

12. Mallawer MM, Marks M, McChesney D, Piasio M, Gunthers F, Shnookler BM. Effect of cryosurgery and polymethyl methacrylate on a tumor cavity: evaluation of bone necrosis and bone graft incorporation in a dog model. In: Enneking WF, editor. Limb salvage in musculoskeletal oncology. New York: Churchill Livingstone; 1987. p. 486-98.

13. Marcove RC, Weis LD, Vaghaiwalla MR, Pearson R. Cryosurgery in the treatment of giant cell tumors of bone: a report of 52 consecutive cases. Clin Orthop. 1978;134:275-89. 
14. Campanacci M, Baldini N, Boriani S, Sudanese A. Giant-cell tumor of bone. J Bone Joint Surg Am. 1987;69:106-14.

15. Enderle A, Willert HG, Zichner L. Morphology of the tissue surrounding a temporary bone cement plug. In: Enneking WF, editor. Limb salvage in musculoskeletal oncology. New York: Churchill Livingstone; 1987. p. $470-5$.

16. Feith R. Side effects of acrylic cemented implanted in bone. Acta Orthop Scand. 1975;161(Suppl):3-136.

17. Linder L. Reaction of bone to the acute chemical trauma of bone cement. J Bone Joint Surg Am. 1977;59:82-7.
18. Mjoberg B, Petterson H, Rosenqvist R, Rydholm A. Bone cement, thermal injury and the radiolucent zone. Acta Orthop Scand. 1984;55:597-600.

19. Reckling FW, Dillon W. The bone-cement interface temperature during total joint replacement. J Bone Joint Surg Am. 1977;59:80-2.

20. Schultz RJ, Johnston AD, Krishnamurthy S. Thermal effects of polymerization of methylmethacrylate on small tubular bones. Int Orthop. 1987;11:277-82. 